(c) American Dairy Science Association, 2005.

\title{
Heritabilities, Genetic Correlations, and Genetic Change for Female Fertility and Protein Yield in Norwegian Dairy Cattle
}

\author{
I. M. Andersen-Ranberg, ${ }^{1,2}$ G. Klemetsdal, ${ }^{1}$ B. Heringstad, ${ }^{1,2}$ and T. Steine ${ }^{2}$ \\ ${ }^{1}$ Department of Animal and Aquacultural Sciences, \\ Agricultural University of Norway, N-1432 Ås, Norway \\ ${ }^{2}$ GENO Breeding and A.I. Association, N-1432 Ås, Norway
}

\section{ABSTRACT}

Data from 1,815,581 first insemination records from daughters of 2697 Norwegian Dairy Cattle (NRF) sires were analyzed. A multitrait model was used to estimate genetic parameters and genetic change for 56-d nonreturn rate in virgin heifers (NR56D0), for 56-d nonreturn rate in first lactation cows (NR56D1L), for interval from calving to first insemination (CFI1L), and for protein yield $\left(\mathrm{PY}_{305} 1 \mathrm{~L}\right)$. The heritabilities for NR56D0, NR56D1L, CFI1L, and PY ${ }_{305} 1 \mathrm{~L}$ were 1.08, 0.99, 3.01, and $20.80 \%$, respectively. Genetic correlation between heifer and cow fertility was high and favorable between NR56D0 and NR56D1L (0.54) and moderate and unfavorable between NR56D0 and CFI1L (0.24). The genetic correlations between NR56D1L and CFI1L and between NR56D0 and PY $3051 \mathrm{~L}$ were 0.08 and 0.04, respectively. A small, unfavorable genetic correlation between NR56D1L and PY $\mathrm{P}_{305} 1 \mathrm{~L}(-0.18)$ was found, while the genetic correlation between $\mathrm{PY}_{305} 1 \mathrm{~L}$ and CFI1L was strongly unfavorable (0.47). Since $1972, \mathrm{NRF}$ sires have been selected for NR56D0 using breeding values estimated from large progeny groups and with considerable weight in the total merit index. A linear regression analysis of sire PTA on year of first insemination of daughters showed an annual genetic change of $0.14 \%$ units for NR56D0. Selection was able to stabilize the genetic change of NR56D1L (0.03\%/yr) but an undesirable change for CFI1L $(0.11 \mathrm{~d} / \mathrm{yr})$ was found. The change of sire PTA for PY $3051 \mathrm{~L}$ was $0.63 \mathrm{~kg} / \mathrm{yr}$.

(Key words: nonreturn rate, interval from calving to first insemination, protein yield, multitrait model)

Abbreviation key: CFI1L = interval from calving to first insemination in first-lactation cows, $\mathbf{N R F}=$ Norwegian Dairy Cattle, NR56D0 $=56$ - d nonreturn rate in virgin heifers, NR56D1L $=56$-d nonreturn rate in first-lactation cows, $\mathbf{P Y}_{\mathbf{3 0 5}} \mathbf{1 L}=$ first-lactation 305-d protein yield.

Received June 11, 2004.

Accepted August 26, 2004.

Corresponding author: I. M. Andersen-Ranberg; e-mail: ina. ranberg@iha.nlh.no.

\section{INTRODUCTION}

In most countries, the primary selection objective in dairy cattle breeding has been milk production. Recently, functional traits such as reproduction and health traits have received increased focus because of biological, economical, and ethical reasons, and also animal welfare concerns. The genetic correlations between female fertility and milk production are antagonistic (Janson and Andréasson, 1981; Hermas et al., 1987; Dematawewa and Berger, 1998; Kadarmideen et al., 2000; Royal et al., 2002). Selection for increased milk yield is, therefore, expected to result in genetic decline in female fertility, implying that selection for fertility is necessary to genetically stabilize or improve female fertility. One can also argue that fertility is economically important, as Boichard (1990) has shown that herds with the same production level, but with 45 and $60 \%$ average conception rates, respectively, differed in overall income by $10 \%$. Given that fertility has a substantial economic value, as assumed in the Nordic countries for example, selection based on fertility information will increase the accuracy of selection on the aggregate economic genotype. This has been demonstrated by Lindhé and Philipsson (1998), who found a $10 \%$ improvement in accuracy and increased total gain from including information on fertility and health in the total merit index. A consequence will be a 12 to $13 \%$ reduced genetic gain in milk production.

Female fertility has been included in the total merit index for Norwegian Dairy Cattle (NRF) since 1972. The relative weight on fertility has been between 8 and $15 \%$ over the entire period. Since 1972, the trait used in selection was 56-d nonreturn rate in virgin heifers (NR56D0). Since 2002, a combination of NR56D0 and 56-d nonreturn rates in first-lactation cows (NR56D1L) has been used.

Female fertility is a complex trait that can be divided into at least 2 components: interval traits and success traits. One of the most widely used interval traits is the interval from calving to first insemination, which describes the ability of a cow to show estrus after calving. Success traits, such as nonreturn rates, are related 
to the capability of a heifer or a cow to conceive when inseminated. The advantages of interval from calving to first insemination and 56-d nonreturn rate are that they are available earlier and are less biased because of selection than other fertility traits. The disadvantages of interval from calving to first insemination are that it may be influenced by farmer decisions, e.g., that high-yielding cows are inseminated later than those producing less, or by seasonal calving. The 56-d nonreturn rate may be affected by culling decisions made after first insemination, lack of recording of natural services, inseminations done later than $56 \mathrm{~d}$ after first insemination, and the fact that $56-\mathrm{d}$ nonreturn is a categorical trait.

The physiological status of virgin heifers is quite different from that of milking cows because stress of lactation and calving difficulties affect fertility traits (Weigel and Rekaya, 2000; Miller et al., 2001). Despite this, Janson (1980) and Distl (1982) found high genetic correlations between heifer and cow fertility. In other studies, low or zero correlations have been reported (Hansen et al., 1983; Raheja et al., 1989). However, reported standard errors in these studies were large.

The objectives of this study were to estimate heritabilities, genetic correlations, and genetic changes in NRF for NR56D0, NR56D1L, interval from calving to first insemination in first lactation cows (CFI1L), and 305-d protein yield in first lactation $\left(\mathbf{P Y}_{\mathbf{3 0 5}} \mathbf{1 L}\right)$, using data from 1978 onward.

\section{MATERIALS AND METHODS}

\section{Data}

Data were obtained from the Norwegian Dairy Herd Recording System from 1978 onward (Heringstad et al., 1999). The data flow of insemination records is described by Andersen-Ranberg et al. (2003a), and a data set was extracted for multivariate analysis including a total of 1,815,581 records. Both first and second crop daughters of the $2697 \mathrm{NRF}$ sires that have been progeny tested after 1980 were included. For NR56D0, NR56D1L, and CFI1L, the data were restricted to heifers or first-lactation cows with first insemination in the period from September 1, 1978 to November 1, 1998. Protein yield data were restricted to include only cows with a complete 305-d lactation. If a cow had recorded veterinary treatment of abortion, silent estrus, or estrus synchronization, the records for NR56D0, NR56D1L, and CFI1L were discarded because these treatments affect the traits. Information of NR56D0 and NR56D1L was rejected if the heifer or cow was culled earlier than $56 \mathrm{~d}$ after first insemination. A NR56D0 record was accepted if age at first insemination was between 44 and 135 wk. For NR56D1L, CFI1L,
Table 1. Number of records for each trait combination of 56-d nonreturn rates for heifers (NR56D0), 56-d nonreturn rate for first lactation cows (NR56D1L), the interval from calving to first insemination (CFI1L), and 305-d protein yield (PY $\left.{ }_{305} 1 \mathrm{~L}\right)$. Total number of records: $1,815,581$.

\begin{tabular}{lrlll}
\hline & NR56D0 & NR56D1L & CFI1L & PY $_{305} 1 \mathrm{~L}$ \\
\hline NR56D0 & $1,524,328$ & - & - & - \\
NR56D1L & 988,773 & $1,176,323$ & - & - \\
CFI1L & 986,636 & $1,154,020$ & $1,172,597$ & - \\
PY $3051 \mathrm{~L}$ & 909,771 & $1,006,009$ & $1,005,443$ & $1,166,646$ \\
\hline
\end{tabular}

and $\mathrm{PY}_{305} 1 \mathrm{~L}$, cows with age at first calving between 80 and $171 \mathrm{wk}$ were included. The accepted interval for CFI1L was between 20 and $210 \mathrm{~d}$, and the period from calving to November 1, 1998 had to be at least $210 \mathrm{~d}$. Double insemination was defined as a new insemination occurring within 0 to $5 \mathrm{~d}$ after first insemination. The $\mathrm{PY}_{305} 1 \mathrm{~L}$ records were restricted to cows with first calving between September 1, 1978 and April 19, 1998. Additional editing for $\mathrm{PY}_{305} 1 \mathrm{~L}$ was as described by Heringstad et al. (2003).

The 2 nonreturn variables were defined as binary traits, based on whether the heifer or cow had a second insemination within $56 \mathrm{~d}$ after the first insemination. The nonreturn rates were based on first insemination only. The resulting data set contained 1,524,328 and 1,176,323 records for NR56D0 and NR56D1L, respectively (Table 1). The yearly phenotypic averages for the 4 traits are shown in Figures 1 and 2. The years 1978, 1979 , and 1998 were only partially represented in the data and were therefore excluded from the figures. Figure 1 depicts the phenotypic average of NR56D0, increasing 2.2\% units from 1979 to 1997, while NR56D1L increased phenotypically by $1.4 \%$ units from 1980 to 1997. The overall mean nonreturn rates were 74.4 and $66.9 \%$ for NR56D0 and NR56D1L, respectively (Table

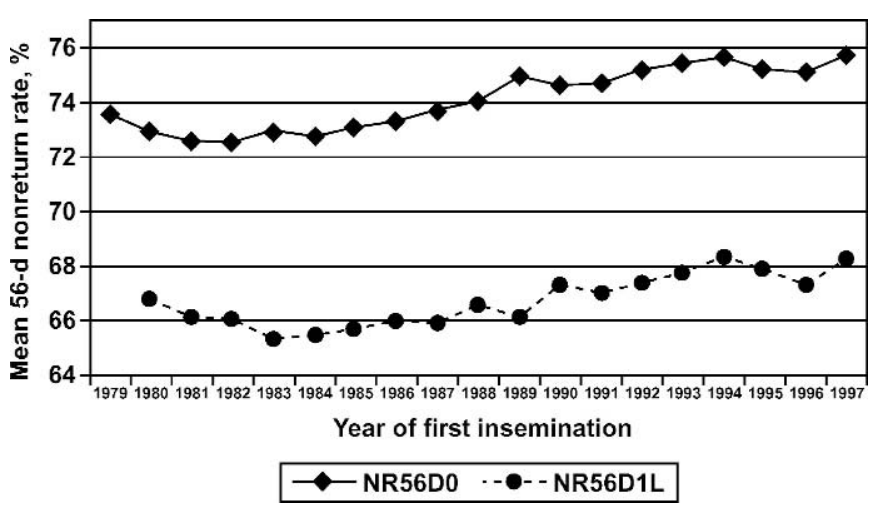

Figure 1. Phenotypic trends for 56-d nonreturn rate in Norwegian dairy cattle heifers (NR56D0) and 56-d nonreturn rate for first lactation cows (NR56D1L). 


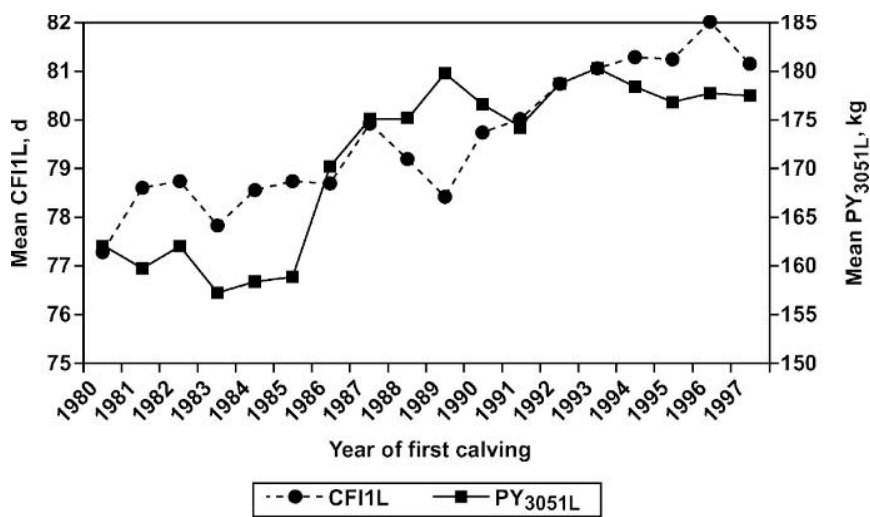

Figure 2. Phenotypic trends of interval from calving to first insemination $(\mathrm{CFI} 1 \mathrm{~L})$ and $305-\mathrm{d}$ protein yield $\left(\mathrm{PY}_{305} 1 \mathrm{~L}\right)$.

2). In total there were $1,172,597$ records of CFI1L (Table 1 ), and the overall mean CFI1L was $80.0 \mathrm{~d}$ (Table 2). The data set used in the analysis had 1,166,646 records of $\mathrm{PY}_{305} 1 \mathrm{~L}$ (Table 1), with an average of $172.6 \mathrm{~kg}$ (Table 2). Phenotypic trends for CFI1L and PY $3051 \mathrm{~L}$ are shown in Figure 2. The CFI1L increased with $3.9 \mathrm{~d}$ in the period from 1980 to 1997 , while $\mathrm{PY}_{305} 1 \mathrm{~L}$ increased with $15.6 \mathrm{~kg}$ during the same period. The number of records for each trait combination is given in Table 1, e.g., there were 909,771 cows with records for both NR56D0 and $\mathrm{PY}_{305} 1 \mathrm{~L}$.

A total of $2696 \mathrm{NRF}$ sires were represented in the data. A sire pedigree file, including the sire and paternal grandsire, was built by tracing the pedigree through sires back as many generations as possible. This resulted in a pedigree file with a total of 2786 males, the oldest born in 1940 .

\section{Model}

(Co)variance components and PTA were calculated using a multivariate linear sire model. The model for

Table 2. Summary statistics of the data used for analyses of 56-d nonreturn rates for heifers (NR56D0), 56-d nonreturn rate for firstlactation cows (NR56D1L), interval from calving to first insemination (CFI1L), and 305-d protein yield $\left(\mathrm{PY}_{305} 1 \mathrm{~L}\right)$.

\begin{tabular}{lr}
\hline Sires, no. & 2696 \\
Daughters per sire, mean no. & 674 \\
Herd-year (NR56D0) of first insemination classes, & \\
no. & 362,362 \\
Herd-year (NR56D1L) of first calving classes, no. & 346,754 \\
Herd-year (CFI1L) of first calving classes, no. & 343,382 \\
Herd-year (PY ${ }_{305} 1 \mathrm{~L}$ ) of first calving classes, no. & 356,411 \\
Mean NR56D0, \% & 74.4 \\
Mean NR56D1L, $\%$ & 66.9 \\
Mean CFI1L, d & 80.0 \\
Mean PY & 172.6 \\
Insemination, yr & 1978 to 1998 \\
First calving, yr & 1979 to 1998 \\
\hline
\end{tabular}

NR56D0 was the one recommended by Andersen-Ranberg et al. (2003b):

$$
\mathrm{Y}_{\mathrm{ijklmn}}=\mathrm{A}_{\mathrm{i}}+\mathrm{M}_{\mathrm{j}}+\mathrm{DI}_{\mathrm{k}}+\mathrm{hy}_{\mathrm{l}}+\mathrm{s}_{\mathrm{m}}+\mathrm{e}_{\mathrm{ijklmn}}
$$

where

$$
\begin{aligned}
\mathrm{Y}_{\mathrm{ijklmn}}= & \text { observation of NR56D0 }(0=\text { return, } 1=\text { non- } \\
& \text { return }) \text { of daughter } \mathrm{n} ; \\
\mathrm{A}_{\mathrm{i}}= & \text { fixed effect of age } \mathrm{i} \text { at first insemination, in } \\
& \text { weeks, with } 92 \text { classes ranging from } 44 \text { to } \\
& 135 \text { wk; } \\
\mathrm{M}_{\mathrm{j}}= & \text { fixed effect of month } \mathrm{j} \text { at first insemination, } \\
& \text { in } 12 \text { classes; } \\
\mathrm{DI}_{\mathrm{k}}= & \text { fixed effect of double insemination } \mathrm{k} \text {, in } 2 \\
& \text { classes; } \\
\mathrm{hy}_{\mathrm{l}}= & \text { random effect of herd-year at first insemina- } \\
& \text { tion l; } \\
\mathrm{S}_{\mathrm{m}}= & \text { random effect of sire } \mathrm{m} \text {; and } \\
\mathrm{e}_{\mathrm{ijk} \mathrm{kn} n}= & \text { random residual term. }
\end{aligned}
$$

The models for NR56D1L and CFI1L were validated accordingly to the model validation used for NR56D0 (Andersen-Ranberg et al., 2003b). For these traits, models with fixed effect of month-year showed less bias than models containing only fixed effect of month.

Therefore, the model for NR56D1L became

$$
\mathrm{Y}_{\mathrm{ijklmn}}=\mathrm{AC}_{\mathrm{i}}+\mathrm{MY}_{\mathrm{j}}+\mathrm{DI}_{\mathrm{k}}+\mathrm{hy}_{\mathrm{l}}+\mathrm{s}_{\mathrm{m}}+\mathrm{e}_{\mathrm{ijklmn}}
$$

where

$$
\begin{aligned}
\mathrm{Y}_{\mathrm{ijklmn}}= & \text { observation of NR56D0 }(0=\text { return, } 1=\text { non- } \\
& \text { return }) \text { of daughter } \mathrm{n} ; \\
\mathrm{AC}_{\mathrm{i}}= & \text { fixed effect of age } \mathrm{i} \text { at first calving in weeks, } \\
& \text { with } 82 \text { classes; the first class for } 80 \text { to } 85 \mathrm{wk}, \\
& \text { separate classes for successive weeks and the } \\
& \text { last class for } 165 \text { to } 171 ; \\
\mathrm{MY}_{\mathrm{j}}= & \text { fixed effect of month-year } \mathrm{j} \text { at first insemina- } \\
& \text { tion, in } 232 \text { classes; } \\
\mathrm{DI}_{\mathrm{k}}= & \text { fixed effect of double insemination } \mathrm{k} \text {, in } 2 \\
& \text { classes; } \\
\mathrm{hy}_{\mathrm{l}}= & \text { random effect of herd-year at first calving, } \mathrm{l} ; \\
\mathrm{S}_{\mathrm{m}}= & \text { random effect of sire m; and } \\
\mathrm{e}_{\mathrm{ijk} \mathrm{k} n \mathrm{~m}}= & \text { random residual term. }
\end{aligned}
$$

The model for CFI1L was

$$
\mathrm{Y}_{\mathrm{ijklm}}=\mathrm{AC}_{\mathrm{i}}+\mathrm{MYC}_{\mathrm{j}}+\mathrm{hy}_{\mathrm{k}}+\mathrm{s}_{\mathrm{l}}+\mathrm{e}_{\mathrm{ijklm}}
$$

where

$\mathrm{Y}_{\mathrm{ijklm}}=$ observation of CFI1L of daughter m; $\mathrm{AC}_{\mathrm{i}}=$ fixed effect of age $\mathrm{i}$ at first calving, in weeks, 
with 82 classes; the first class for 80 to 85 wk, separate classes for successive weeks and the last class for 165 to 171 ;

$\mathrm{MYC}_{\mathrm{j}}=$ fixed effect of month-year $\mathrm{j}$ at first calving, in 228 classes;

$\mathrm{hy}_{\mathrm{k}}=$ random effect of herd-year at first calving $\mathrm{k}$;

$\mathrm{S}_{\mathrm{l}}=$ random effect of sire 1 ; and

$\mathrm{e}_{\mathrm{ijklm}}=$ random residual term .

The model for $\mathrm{PY}_{305} 1 \mathrm{~L}$ was the same as the one used by Heringstad et al. (2003), except that the effect of days open was removed from the model for $\mathrm{PY}_{305} 1 \mathrm{~L}$, as one aim of the present study was to estimate correlations between CFI1L and $\mathrm{PY}_{305} 1 \mathrm{~L}$.

The model for $\mathrm{PY}_{305} 1 \mathrm{~L}$ was

$$
\mathrm{Y}_{\mathrm{ijklm}}=\mathrm{AC}_{\mathrm{i}}+\mathrm{MYC}_{\mathrm{j}}+\mathrm{hy}_{\mathrm{k}}+\mathrm{s}_{\mathrm{l}}+\mathrm{e}_{\mathrm{ijklm}}
$$

where

$$
\begin{aligned}
\mathrm{Y}_{\mathrm{ijklm}}= & \text { observation of } 305-\mathrm{d} \text { protein yield (kg pro- } \\
& \text { tein) of daughter m; and other effects were as } \\
& \text { defined for CF1L, with } 236 \text { classes for } \mathrm{MYC}_{\mathrm{j}} .
\end{aligned}
$$

The following (co)variance structures were assumed for random effects:

$$
\text { hy } \sim \mathrm{N}(0, \mathbf{H} \otimes \mathrm{I}), \mathrm{s} \sim \mathrm{N}(0, \mathbf{G} \otimes \mathrm{A}) \text {, and } \mathbf{e} \sim \mathrm{N}(0, \mathbf{R} \otimes \mathrm{I})
$$

where

$$
\begin{aligned}
\mathbf{H} & =\left[\begin{array}{cccc}
\sigma_{h y 1}^{2} & 0 & 0 & 0 \\
0 & \sigma_{h y 2}^{2} & \sigma_{h y 2 h y 3} & \sigma_{h y 2 h y 4} \\
0 & \sigma_{h y 3 h y 2} & \sigma_{h y 3}^{2} & \sigma_{h y 3 h y 4} \\
0 & \sigma_{h y 4 h y 2} & \sigma_{h y 4 h y 3} & \sigma_{h y 4}^{2}
\end{array}\right], \\
\mathbf{G} & =\left[\begin{array}{cccc}
\sigma_{s 1}^{2} & \sigma_{s 1 s 2} & \sigma_{s 1 s 3} & \sigma_{s 1 s 4} \\
\sigma_{s 2 s 1} & \sigma_{s 2}^{2} & \sigma_{s 2 s 3} & \sigma_{s 2 s 4} \\
\sigma_{s 3 s 1} & \sigma_{s 3 s 2} & \sigma_{s 3}^{2} & \sigma_{s 3 s 4} \\
\sigma_{s 4 s 1} & \sigma_{s 4 s 2} & \sigma_{s 4 s 3} & \sigma_{s 4}^{2}
\end{array}\right] \text {, and } \\
\mathbf{R} & =\left[\begin{array}{cccc}
\sigma_{e 1}^{2} & \sigma_{e 1 e 2} & \sigma_{e 1 e 3} & \sigma_{e 1 e 4} \\
\sigma_{e 2 e 1} & \sigma_{e 2}^{2} & \sigma_{e 2 e 3} & \sigma_{e 2 e 4} \\
\sigma_{e 3 e 1} & \sigma_{e 3 e 2} & \sigma_{e 3}^{2} & \sigma_{e 3 e 4} \\
\sigma_{e 4 e 1} & \sigma_{e 4 e 2} & \sigma_{e 4 e 3} & \sigma_{e 4}^{2}
\end{array}\right] ;
\end{aligned}
$$

and $\mathbf{H}, \mathbf{G}$, and $\mathbf{R}$ are (co)variance matrices among the 4 traits for effects of herd-year, sire, and residual, respectively. A was the additive relationship matrix, and I was an identity matrix. The REML estimates of the (co)variance components and PTA, given the estimated (co)variance components, were calculated using the DMU package (Jensen and Madsen, 1994).

\section{RESULTS AND DISCUSSION}

\section{Heritabilities}

The REML estimates of variance components and corresponding heritabilities for the 4 traits are shown in Table 3. Sire variance for NR56D1L was found to be slightly larger than the sire variance of NR56D0. Estimated heritability for NR56D0 (Table 3) within herds was small $(1.08 \%)$. This is in agreement with Pedersen and Jensen (1996) and Distl (1982), who found heritability estimates for 56-d and 60-d nonreturn rates in virgin heifers with linear models to be 0.8 and $1.1 \%$, respectively. For NR56D1L, the heritability estimate was close to that in virgin heifers $(0.99 \%)$. The corresponding estimate by Wall et al. (2003) for 56-d nonreturn in first lactation was higher (1.8\%). Weigel and Rekaya (2000), using a linear model, found heritabilities of 1.4 and $4.1 \%$ for 60 -d nonreturn in California and Minnesota Holstein, respectively. However, these estimates cannot be compared directly, as nonreturn has a categorical outcome, making heritability estimates from linear models frequency dependent.

The heritability for CFI1L within herds was estimated as $3.01 \%$ (Table 3). The corresponding estimate by Roxström et al. (2001) was $3.37 \%$. Other published heritability estimates for CFI1L range from 3.0 to $4.0 \%$ (Berger et al., 1981; Hoekstra et al., 1994; Pryce et al., 1998; Dechow et al., 2001; Wall et al., 2003).

As shown in Table 3, heritability of $\mathrm{PY}_{305} 1 \mathrm{~L}$ was found to be $21 \%$. This is in agreement with previous estimates from Norwegian data (Heringstad et al., 1999, 2003), but low compared with results of other recent studies (e.g., Kadarmideen et al., 2000; Roxström et al., 2001; Veerkamp et al., 2001).

\section{Genetic Correlations}

The estimated genetic correlations between the 4 traits and their standard errors are shown in Table 4. The genetic correlation between NR56D0 and NR56D1L was found to be favorable and as high as 0.54 , which was equal to an estimate found by Hodel et al. (1995) in a bivariate analysis of 90-d nonreturn rate in heifers and in first lactation cows. A corresponding high estimate (0.55) was found by Oltenacu et al. (1991) in Swedish Red (former Swedish Red and White), between first service pregnancy in heifers and first lactation cows. In a Dutch study, De Jong (1997) found a lower genetic correlation (0.12) between NR56D0 and NR56D1L. 
Table 3. Variance components and heritability $\left(\mathrm{h}^{2}\right)$ estimates of 56-d nonreturn rates for heifers (NR56D0), 56-d nonreturn rate for first lactation cows (NR56D1L), interval from calving to first insemination (CFI1L), and 305-d protein yield $\left(\mathrm{PY}_{305} 1 \mathrm{~L}\right)$. Standard errors of variances for the random effects are in brackets.

\begin{tabular}{lcccc}
\hline & NR56D0 & NR56D1L & CFI1L & PY $_{305} 1 \mathrm{~L}$ \\
\hline Sire variance $\left(\sigma_{\mathrm{s}}^{2}\right)$ & $4.99 \times 10^{-4}$ & $5.27 \times 10^{-4}$ & 5.05 & 32.67 \\
& $\left(0.31 \times 10^{-4}\right)$ & $\left(0.38 \times 10^{-4}\right)$ & $(0.25)$ & $(1.09)$ \\
Herd-year variance $\left(\sigma_{\text {hy }}^{2}\right)$ & $3.84 \times 10^{-3}$ & $7.48 \times 10^{-3}$ & 155.22 & 510.18 \\
& $\left(0.10 \times 10^{-3}\right)$ & $\left(0.17 \times 10^{-3}\right)$ & $(0.93)$ & $(1.78)$ \\
Residual variance $\left(\sigma_{\mathrm{e}}^{2}\right)$ & $1.85 \times 10^{-1}$ & $2.13 \times 10^{-1}$ & 666.61 & 595.70 \\
& $\left(0.23 \times 10^{-3}\right)$ & $\left(0.21 \times 10^{-3}\right)$ & $(1.02)$ & $(0.93)$ \\
Total variance & $1.89 \times 10^{-1}$ & $2.22 \times 10^{-1}$ & 826.88 & 1138.54 \\
$\mathrm{~h}^{2}=\left(4 \sigma_{\mathrm{s}}^{2} /\right.$ total variance $)$ & $1.05 \times 10^{-2}$ & $0.96 \times 10^{-2}$ & $2.44 \times 10^{-2}$ & $11.48 \times 10^{-2}$ \\
$\mathrm{~h}^{2}=\left(4 \sigma_{\mathrm{s}}^{2} / \sigma_{\mathrm{s}}^{2}+\sigma_{\mathrm{e}}^{2}\right)$ & $1.08 \times 10^{-2}$ & $0.99 \times 10^{-2}$ & $3.01 \times 10^{-2}$ & $20.80 \times 10^{-2}$ \\
\hline
\end{tabular}

The estimated genetic correlations between nonreturn rates and CFI1L were low and unfavorable $(0.24$ and 0.08 , respectively). The estimated correlation between NR56D0 and CFI1L corresponds well with the estimate of 0.30 reported by De Jong (1997). Pedersen and Jensen (1996) also found low correlations between indexes of 56-d nonreturn rate in heifers and indexes of interval from calving to first insemination in cows in Danish Jersey (0.07) and Danish Holstein (former Danish Black and White) (0.11). However, their study did not only include first lactation cows.

The estimated genetic correlation between NR56D0 and $\mathrm{PY}_{305} 1 \mathrm{~L}$ was close to zero (0.04; Table 4$)$. This corresponds with estimates obtained in Finnish Ayrshire by Mäntysaari and Van Vleck (1989), who estimated favorable genetic correlations of 0.14 and 0.03 between 120-d nonreturn in heifers and 305-d 4\% fat-corrected milk, in 2 datasets. However, in the study by Hodel et al. (1995), the correlation between 90-d nonreturn in virgin heifers and milk yield was found to be unfavorable $(-0.21)$.

The genetic correlation between NR56D1L and CFI1L was estimated to be 0.08 (Table 4 ), which was in agreement with the result of Hoekstra et al. (1994), who found a correlation of 0.13 . In contrast, Janson and Andrèasson (1981) found a favorable correlation $(-0.34)$ between 168-d nonreturn and CFI1L in Swedish Red, but the standard error was high (0.15). The estimated

Table 4. Estimates of genetic correlations among 56-d nonreturn rate in heifers (NR56D0), 56-d nonreturn rate for first-lactation cows (NR56D1L), interval from calving to first insemination (CFI1L), and 305-d protein yield $\left(\mathrm{PY}_{305} 1 \mathrm{~L}\right)$, above the diagonal, and SE of correlations below the diagonal.

\begin{tabular}{|c|c|c|c|c|}
\hline & NR56D0 & NR56D1L & CFI1L & $\mathrm{PY}_{305} 1 \mathrm{~L}$ \\
\hline NR56D0 & - & 0.54 & 0.24 & 0.04 \\
\hline NR56D1L & 0.04 & - & 0.08 & -0.18 \\
\hline CFI1L & 0.04 & 0.04 & - & 0.47 \\
\hline $\mathrm{PY}_{305} 1 \mathrm{~L}$ & 0.03 & 0.03 & 0.02 & - \\
\hline
\end{tabular}

genetic correlation between NR56D1L and $\mathrm{PY}_{305} 1 \mathrm{~L}$ was unfavorable $(-0.18)$, as shown in Table 4.

A genetic correlation of 0.47 (Table 4) was found between CFI1L and PY $3051 \mathrm{~L}$. This is in agreement with other studies reporting genetic correlations of 0.3 to 0.5 between the interval from calving to first insemination and protein yield (Van Arendonk et al., 1989; Hoekstra et al., 1994; Pryce et al., 1998; Kadarmideen et al., 2000; Roxström et al., 2001). The correlation between CFI1L and $\mathrm{PY}_{305} 1 \mathrm{~L}$ may be influenced by individual farmer decisions if high-yielding cows are inseminated later than cows with low or moderate yields. However, most Norwegian farmers prefer to start insemination at second estrus and want to avoid calving intervals $>1 \mathrm{yr}$.

Herd-year and residual (environment) correlations are shown in Table 5. The highest correlation between herd-year effects was between NR56D1L and CFI1L (0.51), suggesting that environments changing one variable, on a herd basis, also change the other. Residual correlations were small, except between $\mathrm{PY}_{305} 1 \mathrm{~L}$ and CFI1L (0.22), showing that environment, favoring a higher milk production on an individual cow level, also results in a longer CFI1L.

\section{Environmental Effects and Genetic Change}

The effect of age at first insemination on NR56D0 increased in the interval from 12.2 to 24.6 mo, which

Table 5. Estimates of herd-year correlations between effect for 56d nonreturn rate for first-lactation cows (NR56D1L), interval from calving to first insemination (CFI1L), and 305-d protein yield $\left(\mathrm{PY}_{305} 1 \mathrm{~L}\right)$, above diagonal, and estimates of residual effect correlation between (NR56D0), NR56D1L, CFI1L, and PY $3051 \mathrm{~L}$ and also $56 \mathrm{~d}$ nonreturn for heifers below the diagonal. ${ }^{1}$

\begin{tabular}{lllll}
\hline & NR56D0 & NR56D1L & CFI1L & PY $_{305} 1 \mathrm{~L}$ \\
\hline NR56D0 & - & - & - & - \\
NR56D1L & 0.04 & - & 0.51 & -0.09 \\
CFI1L & 0.12 & 0.06 & - & 0.03 \\
PY3051L & 0.02 & -0.13 & 0.22 & - \\
\hline
\end{tabular}

${ }^{1} \mathrm{SE}$ of all correlations were $<0.01$. 


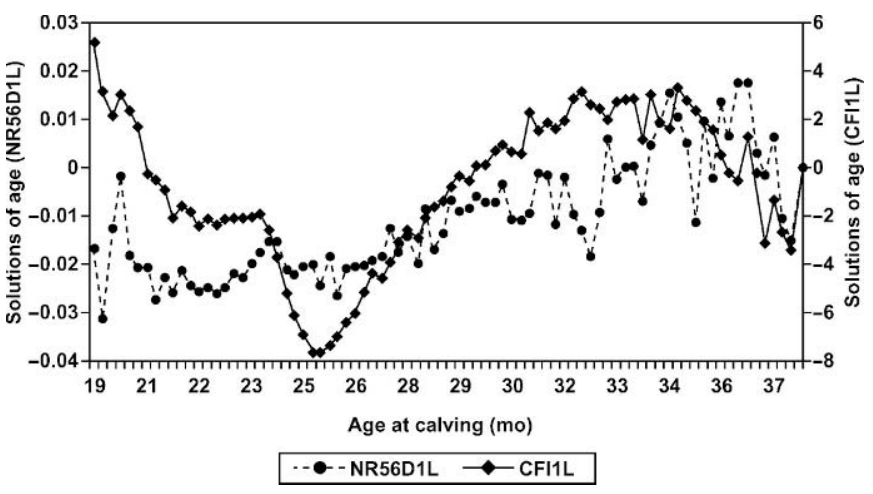

Figure 3. Solutions of age at calving effect for 56-d nonreturn rate in first-lactation cows (NR56D1L) and interval from calving to first insemination (CFI1L).

agrees with the result of Andersen-Ranberg et al. (2003a). The corresponding curve of NR56D1L increased somewhat in the interval from 20.9 to 36.3 mo at first calving (Figure 3). For CFI1L, the solutions for age at first calving decreased in the interval from 19.3 to $25.3 \mathrm{mo}$, and then increased up to $34.7 \mathrm{mo}$ (Figure 3). The $\mathrm{PY}_{305} 1 \mathrm{~L}$ increased linearly with age at first calving over the entire interval.

Effect of month at first insemination on NR56D0 (Figure 4) showed high values for the summer months (May, June, July, and August). The solutions of month-year at first insemination effect for NR56D1L and first calving effects for CFI1L, in a period from January 1990 to January 1996 are shown in Figure 5. The pattern was similar over the entire period. The highest values for NR56D1L were in the summer and autumn, and for these months, CFI1L was lowest. The pattern of effect of month-year of first calving on $\mathrm{PY}_{305} 1 \mathrm{~L}$ was similar over the entire period, with lowest solutions in April, May, and June and highest solutions in August to December. Effects of double inseminations were $0.01(\mathrm{SE}=$

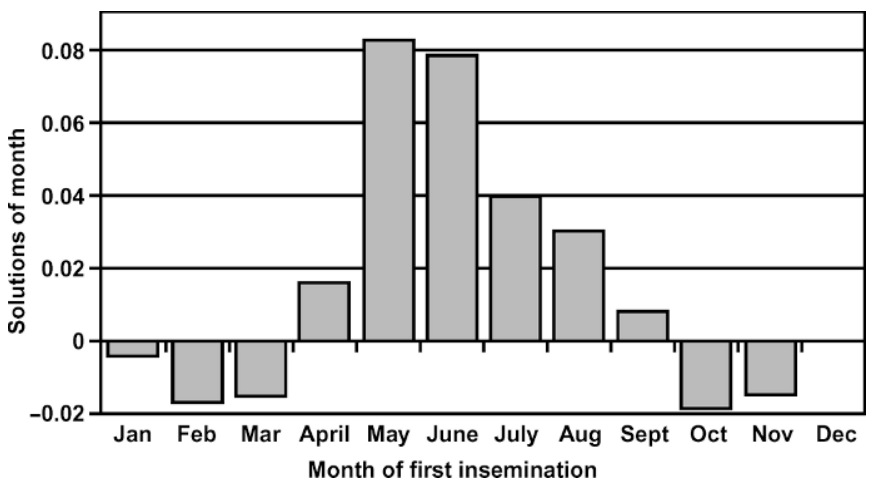

Figure 4. Solutions of month effect for 56-d nonreturn in heifers (NR56D0). December was set at zero.

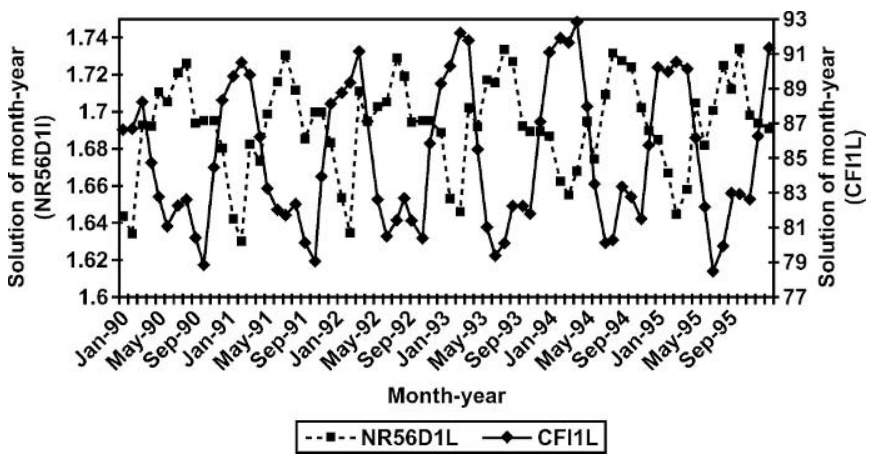

Figure 5. Solutions of month-year at first insemination effect for 56-d nonreturn rate in first-lactation cows (NR56D1L) and solutions of month-year at first calving for interval from calving to first insemination (CFI1L) from January 1990 to January 1996.

$0.001)$ and $0.04(\mathrm{SE}=0.001)$ for NR56D0 and NR56D1L, respectively.

Genetic change for the traits expressed as mean sire PTA by year of daughters' first insemination for NR56D0 and by year of daughters' first calving for NR56D1L, PY $\mathrm{P}_{305} 1 \mathrm{~L}$, and CFI1L are shown in Figures 6 and 7. For NR56D0, mean sire PTA increased in the period from 1980 to 1998 (Figure 6), and a linear regression analysis of sire PTA on year of first insemination of daughters resulted in an estimated annual genetic change of $0.14 \%$ units $(P<0.01)$. For NR56D1L, the development was also positive, with an annual genetic change of $0.03 \%$ units $(P<0.01)$. For CFI1L, however, the genetic change was toward a longer interval from calving to first insemination, i.e., unfavorable. The estimated annual genetic change of CFI1L was $0.11 \mathrm{~d}(P$ $<0.01$ ) in the period from 1980 to 1998 , while the annual genetic change of $\mathrm{PY}_{305} 1 \mathrm{~L}$ was positive, $0.63 \mathrm{~kg}(P<$ $0.01)$.

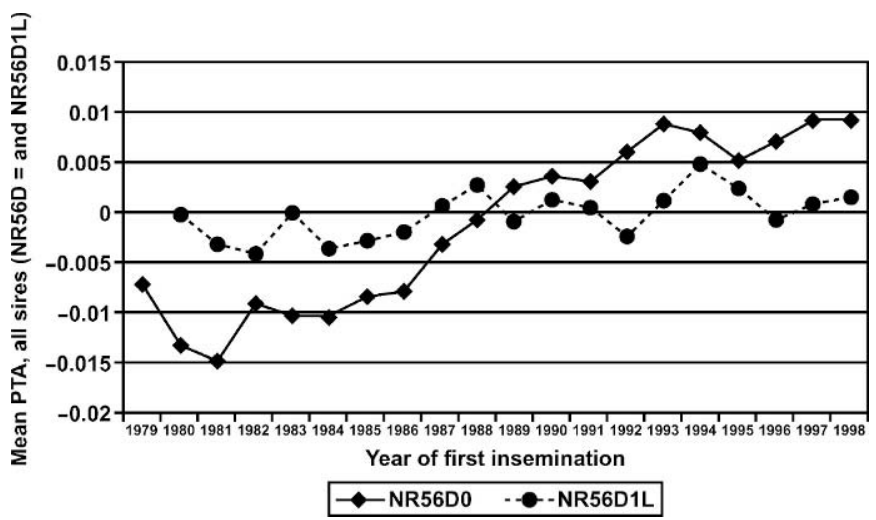

Figure 6. Genetic change of 56-d nonreturn in heifers (NR56D0) and 56-d nonreturn rate for first-lactation cows (NR56D1L), given as mean PTA of sires by year of first insemination for daughters. 


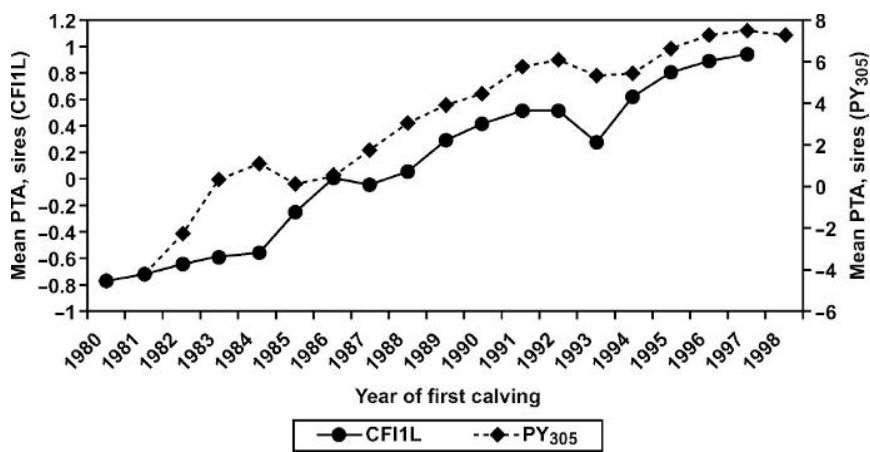

Figure 7. Genetic change of interval from calving to first insemination (CFI1L) and 305-d protein yield $\left(\mathrm{PY}_{305} 1 \mathrm{~L}\right)$, given as mean PTA of sires by year of first calving for daughters.

Figures 6 and 7 show genetic improvement for traits (NR56D0 and $\mathrm{PY}_{305} 1 \mathrm{~L}$ ) that receive considerable weight in NRF's total merit index. Genetic improvement for traits with low heritability, such as NR56D0, is possible because the progeny testing is based on a large number of daughters per sire. The rather different pattern for NR56D1L (nearly unchanged) vs. CFI1L (toward a longer interval) was expected because of the positive genetic correlations between NR56D1L and NR56D0, between CFI1L and NR56D0, and between CFI1L and $\mathrm{PY}_{305} 1 \mathrm{~L}$.

Economic consequences of longer CFI1L depend on milk price, production level, value of the calf, feed cost, and seasonal calving. Strandberg and Oltenacu (1989) found an advantage with short days open, while in Israel (Arbel et al., 2001) there may be some benefit to extended lactations. In Norway, where NRF are used in milk and beef production, a short (e.g., 60 to $90 \mathrm{~d}$ ) CFI1L is probably more profitable. Further research is needed to find the optimal level of the fertility traits and an appropriate combination of the traits in a fertility index.

\section{CONCLUSIONS}

Selection for nonreturn in heifers for $>30 \mathrm{yr}$, using a total merit index where nonreturn rate received a relatively high weight and breeding values for nonreturn rate are estimated from large progeny groups, has resulted in desirable genetic progress for nonreturn rate in heifers. This selection has also genetically stabilized nonreturn in first-lactation cows, but has resulted in an undesirable increase in the interval from calving to first insemination in first lactation. Therefore, the interval from calving to first insemination in first lactation should be included in the fertility index to avoid further increase in the interval from calving to first insemination in first lactation.

\section{ACKNOWLEDGMENTS}

Access to the data was granted in the agreement number 005.2000 by the Norwegian Dairy Herd Recording System on February 24, 2000. GENO Breeding and AI Association are acknowledged for providing pedigree information on sires.

\section{REFERENCES}

Andersen-Ranberg, I. M., B. Heringstad, G. Klemetsdal, M. Svendsen, and T. Steine. 2003a. Heifer fertility in Norwegian dairy cattle. Variance components and genetic change. J. Dairy Sci. 86:2706-2714.

Andersen-Ranberg, I. M., G. Klemetsdal, and B. Heringstad. 2003b. Short communication: Validation of two animal models for estimation of genetic trend for female fertility in Norwegian dairy cattle. J. Dairy Sci. 86:4090-4092.

Arbel, R., Y. Bigun, E. Ezra, H. Sturman, and D. Hojman. 2001. The effect of extended calving intervals in high lactating cows on milk production and profitability. J. Dairy Sci. 84:600-608.

Berger, P. J., R. D. Shanks, A. E. Freeman, and R. C. Laben. 1981. Genetic aspects of milk yield and reproductive performance. J. Dairy Sci. 64:114-122.

Boichard, D. 1990. Estimation of the economic value of conception rate in dairy cattle. Livest. Prod. Sci. 24:187-204.

De Jong, G. 1997. Index for daughters fertility in the Netherlands. Proc. of the Int. Workshop on Genetic Improvement of Functional Traits in Cattle; Fertility and Reproduction, Grub, Germany. INTERBULL Bull. 18:102-105.

Dechow, C. D., G. W. Rogers, and J. S. Clay. 2001. Heritabilities and correlations among body condition scores, production traits, and reproductive performance. J. Dairy Sci. 84:266-275.

Dematawewa, C. M. B., and P. J. Berger. 1998. Genetic and phenotypic parameters for 305-day yield, fertility, and survival in Holsteins. J. Dairy Sci. 81:2700-2709.

Distl, O. 1982. Selection for fertility traits. Proc. 2nd World Congr. Genet. Appl. Livest. Prod., Madrid, Spain. 7:580-585.

Hansen, L. B., A. E. Freeman, and P. J. Berger. 1983. Yield and fertility relationships in dairy cattle. J. Dairy Sci. 66:293-305.

Heringstad, B., G. Klemetsdal, and J. Ruane. 1999. Clinical mastitis in Norwegian cattle: Frequency, variance components, and genetic correlation with protein yield. J. Dairy Sci. 82:1325-1330.

Heringstad, B., G. Klemetsdal, and T. Steine. 2003. Selection responses for clinical mastitis and protein yield in two Norwegian dairy cattle selection experiments. J. Dairy Sci. 86:2990-2999.

Hermas, S. A., C. W. Young, and J. W. Rust. 1987. Genetic relationships and additive genetic variation of productive and reproductive traits in Guernsey dairy cattle. J. Dairy Sci. 70:1252-1257.

Hodel, F., J. Moll, and N. Kuenzi. 1995. Analysis of fertility in Swiss Simmental cattle: Genetic and environmental effects on female fertility. Livest. Prod. Sci. 41:95-103.

Hoekstra, J., A. W. van der Lugt, J. H. J. van der Werf, and W. Ouweltjes. 1994. Genetic and phenotypic parameters for milk production and fertility traits in upgraded dairy cattle. Livest. Prod. Sci. 40:225-232.

Janson, L. 1980. Studies on fertility traits in Swedish dairy cattle. II: Genetic parameters. Acta Agric. Scand. 30:427-436.

Janson, L., and B. Andréasson. 1981. Studies on fertility traits in Swedish dairy cattle. IV: Genetic and phenotypic correlation between milk yield and fertility. Acta Agric. Scand. 31:313-322.

Jensen, J., and P. Madsen. 1994. DMU: A package for the analysis of multivariate mixed models. Proc. 5th World Congr. Genet. Appl. Livest. Prod., Guelph, Canada. Comput. Stat. Software 22: $45-46$.

Kadarmideen, H. N., R. Thompson, and G. Simm. 2000. Linear and threshold model genetic parameters for disease, fertility and milk production in dairy cattle. Anim. Sci. 71:411-419.

Lindhé, B., and J. Philipsson. 1998. Genetic correlations between production with disease resistance and fertility in dairy cattle 
and consequences for total merit selection. Acta Agric. Scand. 48:216-221.

Mäntysaari, E., and L. D. Van Vleck. 1989. Estimation of genetic parameters for production and reproduction in Finnish Ayrshire cattle. J. Dairy Sci. 72:2375-2386.

Miller, R. H., J. S. Clay, and H. D. Norman. 2001. Relationship of somatic cell score with fertility measures. J. Dairy Sci. 84:2543-2548.

Oltenacu, P. A., A. Frick, and B. Lindhé. 1991. Relationship of fertility to milk yield in Swedish cattle. J. Dairy Sci. 74:264-268.

Pedersen, J., and J. Jensen. 1996. Evaluation of female fertility of Danish dairy sires. Pages 72-77 in Proc. Int. Workshop Genet. Improvement of Functional Traits in Cattle, Gembloux, Belgium, January 1996. INTERBULL Bull. no. 12, Int. Bull. Eval. Serv., Uppsala, Sweden.

Pryce, J. E., R. J. Esselmont, R. Thompson, R. F. Veerkamp, M. A. Kossaibati, and G. Simm. 1998. Estimation of genetic parameters using health, fertility and production data from a management recording system for dairy cattle. Anim. Sci. 66:577-584.

Raheja, K. L., E. B. Burnside, and L. R. Schaeffer. 1989. Heifer fertility and its relationship with cow fertility and production traits in Holstein dairy cattle. J. Dairy Sci. 72:2665-2669.
Roxström, A., E. Strandberg, B. Berglund, and U. Emanuelson. 2001. Genetic and environmental correlations among female fertility traits and milk production in different parities of Swedish red and white dairy cattle. Acta Agric. Scand. 51:7-14.

Royal, M. D., A. P. Flint, and J. A. Woolliams. 2002. Genetic and phenotypic relationships among endocrine and traditional fertility traits and production traits in Holstein-Friesian dairy cows. J. Dairy Sci. 85:958-967.

Strandberg, E., and P. A. Oltenacu. 1989. Economic consequences of different calving intervals. Acta Agric. Scand. 39:407-420.

Van Arendonk, J. A. M., R. Hovenier, and W. De Boer. 1989. Phenotypic and genetic association between fertility and production in dairy cows. Livest. Prod. Sci. 21:1-12.

Veerkamp, R. F., E. P. C. Koenen, and G. De Jong. 2001. Genetic correlations among body condition score, yield, and fertility in first-parity cows estimated by random regression models. J. Dairy Sci. 84:2327-2335.

Wall, E., S. Brotherstone, J. A. Woolliams, G. Banos, and M. P. Coffey. 2003. Genetic evaluation of fertility using direct and correlated traits. J. Dairy Sci. 86:4093-4102.

Weigel, K. A., and R. Rekaya. 2000. Genetic parameters for reproductive traits of Holsteins cattle in California and Minnesota. J. Dairy Sci. 83:1072-1080. 